\title{
Seismic hazard map of North and Central America and the Caribbean
}

\author{
Kaye M. Shedlock \\ U.S. Geological Survey, Golden, CO, U.S.A.
}

\begin{abstract}
Minimization of the loss of life, property damage, and social and economic disruption due to earthquakes depends on reliable estimates of seismic hazard. National, state, and local governments, decision makers, engineers, estimates for land use planning organizations, builders, universities, and the general public require seismic hazard construction codes), emergency response building design and construction (including adoption of building decisions, and many more types of risk mitigation. Thess plans, economic forecasts, housing and employment Caribbean is the concatenation of varioustion. The seismic hazard map of North and Central America and the combined maps and documentation prious national and regional maps, involving a suite of approaches. The for any national or regional agency for further useful regional seismic hazard framework and serve as a resource depicts Peak Ground Acceleration (PGA) with a $10 \%$ studies applicable to their needs. This seismic hazard map ground motion parameter that is proportional to force is the of exceedance in 50 years. PGA, a short-period because current building codes that include seismic provision most commonly mapped ground motion parameter able to withstand during an the horizontal force a building should be depicts the likely level of short-period This seismic hazard map of North and Central America and the Caribbean ground motions effect short-period structures $(e . g$. one-to-two earthquakes in a fifty-year window. Short-period in the region generally occur in areas thates (e.g., one-to-two story buildings). The highest seismic hazard values earthquakes.
\end{abstract}

Key words seismic hazard assessment - North America - earthquakes - UN/IDNDR

\section{Introduction}

Greenland and Canada/México/United States comprise the principal landmasses of the North American plate (fig. 1). The seven countries of Central America are the principal landmass of the Caribbean plate, while the smaller Caribbean Island nations serve as the above-sea-level expression of the rest of the plate boundary. Plate boundary processes dominate the seismic

Mailing address: Dr. Kaye M. Shedlock, U.S. Geological Survey, Golden, CO 80225, U.S.A.; e-mail: shedlock@ gldmutt.cr.usgs.gov hazard in North and Central America and the Caribbean. The plate boundaries are either subduction (i.e. the Cocos/Caribbean, Eastern Caribbean, Pacific/North American, Juan de Fuca/ North American) or transform (i.e. Pacific/North American along the San Andreas fault and Gulf of California, the north and south Caribbean plate boundaries). The largest earthquakes recorded in the region have been plate boundary earthquakes, including the 1906 San Francisco, CA (U.S.A.) M 7.9 earthquake, the 1938 (M 8.2), 1949 (M 8.1), 1957 (M 9.1), 1958 (M 8.2), 1964 ( $M$ 9.2), and 1965 ( $M$ 8.7) Alaska/Aleutian earthquakes, the 1928 ( $\boldsymbol{M}$ 8.0), 1932 ( $\boldsymbol{M}$ 8.1) and 1985 (M 8.0) México earthquakes. The 1964 $M$ 9.2 Alaska subduction zone earthquake is the second largest earthquake ever recorded.

Seismic hazard maps depict the levels of chosen ground motions that likely will, or will 


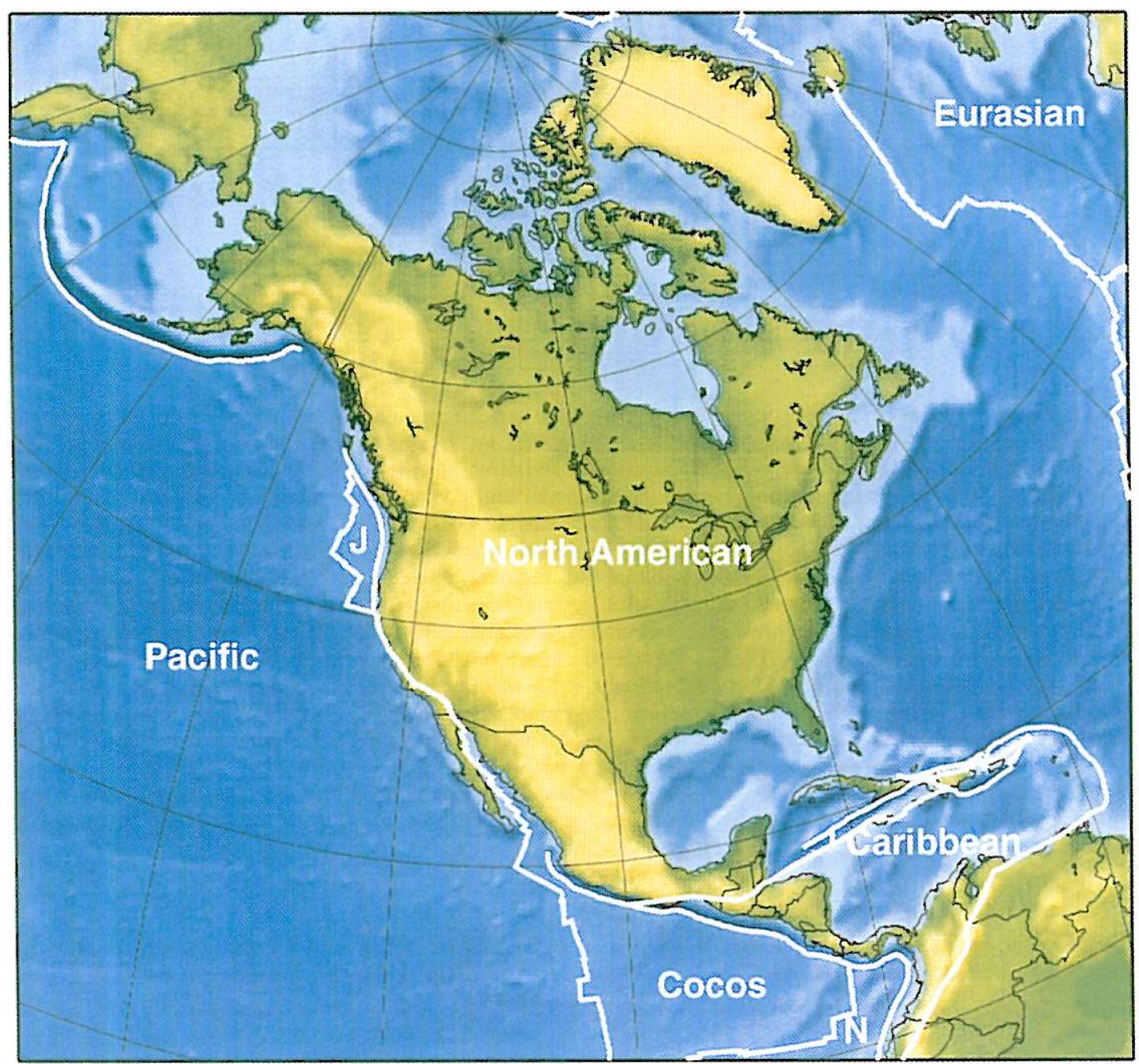

Fig. 1. The major tectonic plates of the North and Central America and the Caribbean are named in white letters. The «J» denotes the Juan de Fuca and the smaller Explorer (north) and Gorda (south) plates. The «N» denotes the Nazca plate. The small Rivera plate abuts the Cocos plate on the northwest.

not, be exceeded in specified exposure times. Hazard assessment programs in the region commonly specify a $10 \%$ chance of exceedance ( $90 \%$ chance on non-exceedance) of some ground motion parameter for an exposure time of 50 years, corresponding to a return period of 475 years. Commonly mapped ground motions are maximum intensity, Peak Ground Accelera- tion (PGA), Peak Ground Velocity (PGV), and several Spectral Accelerations (SA). Each ground motion mapped corresponds to a portion of the bandwidth of energy radiated from an earthquake. PGA and $0.2 \mathrm{~s}$ SA correspond to shortperiod energy that will have the greatest effect on short-period structures (one-to two story buildings, which is the most common building 
stock in the region). Longer-period SA maps $(1.0 \mathrm{~s}, 2.0 \mathrm{~s}$, etc.) depict the level of shaking that will have the greatest effect on longer-period structures $(10+$ story buildings, bridges, etc. $)$. Seismic hazard maps are calculated for a specific site classification (hard rock, soft rock, stiff soil, soil, soft soil, etc.). Hazard values calculated for rock/stiff soil sites (the most common site classifications) are lower than hazard values calculated for soil sites. Often, hazard values for soil sites my be estimated from the rock/stiff soil site values commonly depicted on hazard maps through simple multiplication by a specified factor, but these are no more than rough estimates.

The seismic hazard map of North and Central America and the Caribbean is the concatenation of various national and regional maps, involving a suite of approaches. Each national or regional suite of maps depicts various ground motion parameters as required for national or regional engineering, response, and mitigation needs. The combined maps and documentation provide a useful global seismic hazard framework and serve as a resource for any national or regional agency for further detailed studies applicable to their needs.

Canada, México, and the United States produced national seismic hazard maps. We concatenated these national maps without smoothing discrepancies along their borders, since these maps appear in some form in national or local building codes. Regional seismic hazard maps were produced for Central America and the Caribbean. The methods and data used in the generation of each national or regional map used to produce the North and Central America and the Caribbean map are documented briefly herein, along with the names and contact information for the scientists responsible for the maps. The user is encouraged to contact the appropriate scientists and/or agencies for more detailed information.

\section{Canada}

The Geological Survey of Canada (GSC) and predecessor agencies have been publishing national probabilistic seismic hazard maps since
1953. The Canadian maps are used in the National Building Code of Canada (NBCC) and by structural engineers, the insurance industry, businesses, emergency services, community planners, and the general public. The seismic hazard map of Canada has been updated with new data and/or methodologies in 1970, 1985, and 1995 (Basham et al., 1997). The suite of Canadian hazard maps depicts probabilistic ground motions (PGA, 0.2, 0.5, and 1.0 spectral acceleration, 5\% damping) with a $10 \%$ Probability of Exceedance (PE) in 50 years (return time of 475 years). Complete documentation describing the procedures and input data used to make the current seismic hazard maps of the Canada may be found in several publications (Adams et al., 1996; Basham et al., 1997), and on the World Wide Web (http://www.seismo.nrcan.gc.ca).

\subsection{Seismicity}

The North American/Pacific plate boundary region is complicated along the west coast of Canada. The small Explorer and Juan de Fuca plates are subducting beneath North America off the southwest coast of Canada and along Vancouver Island (fig. 1), at the northern end of the Cascadia Subduction zone. North of the Explorer plate, the Pacific/North America plate boundary is a transform boundary until it becomes a subduction boundary again near the Alaska/Canada border (fig. 1).

The historical catalog for Canada begins in 1568. The instrumental recording of earthquakes in Canada began in the early twentieth century, but the major expansion of the Canadian national network occurred in 1961. Prior to this time parts of Canada, particularly Northern Canada, were poorly monitored (Basham et al., 1985). Seismicity in Canada is concentrated along the North American/Pacific plate boundary region (fig. 2). Other areas of active seismicity include the Yukon/Northwest Territories, Southeastern Canada (near the U.S. border), and along the Arctic margin (fig. 2). The earthquakes in Eastern Canada include the six $\boldsymbol{M} \approx 6.0$ Charlevoix earthquakes since 1663, the 1929 M 7.2 Grand Banks, and the 1933 M 7.3 Baffin Bay earthquakes. The seismicity in the Yukon/Northwest 


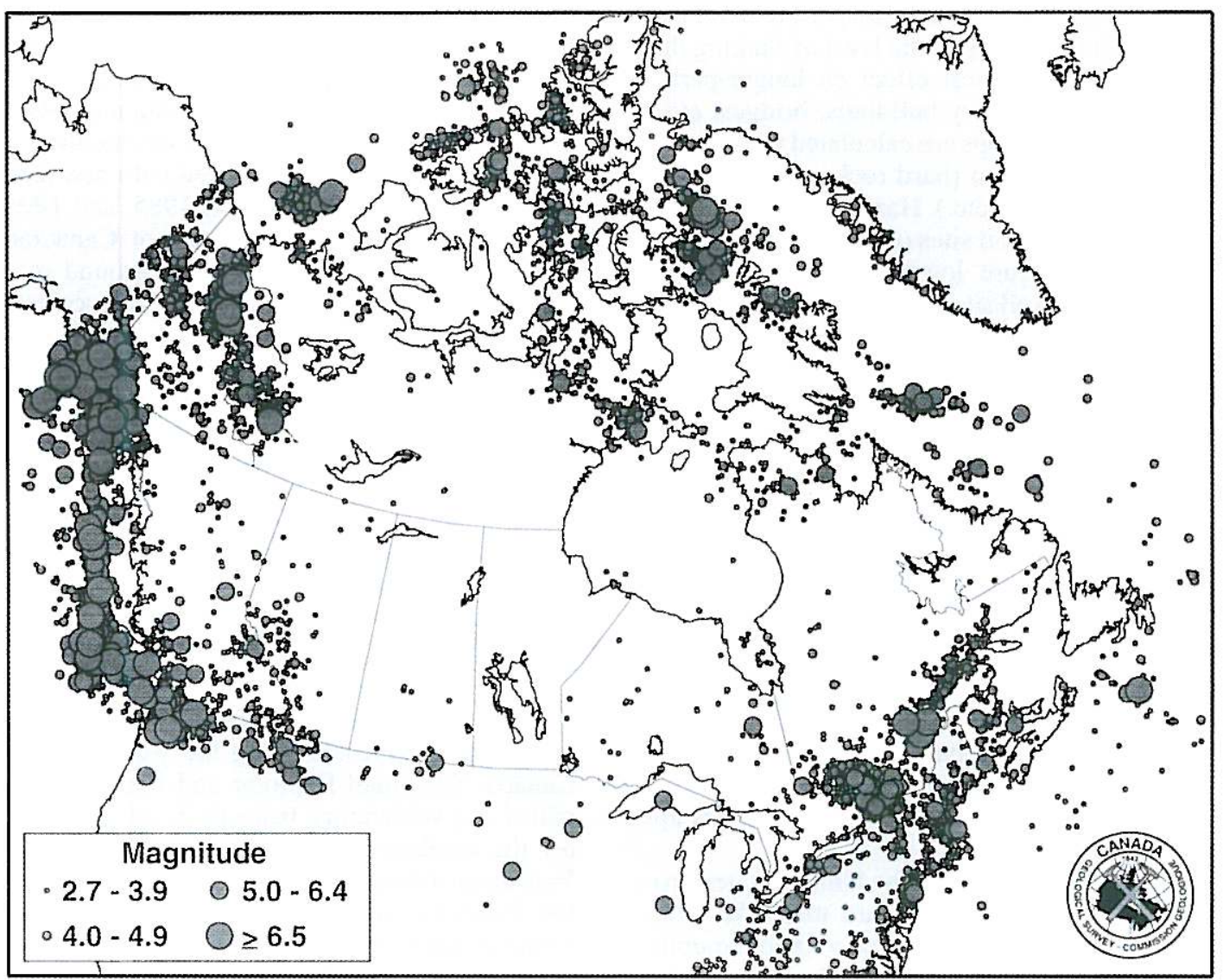

Fig. 2. Seismicity database used to determine Canadian seismic hazard. Damaging earthquakes in or near Canada are concentrated along the west coast (the plate boundary region). Other seismically active areas include the Yukon Territory (abutting Alaska), Southeastern Canada, and the Arctic margin. (Figure provided courtesy of S. Halchuk).

Territories includes the 1985 Nahanni sequence (mainshock $M \approx 6.6$, at least one $M \approx 6.0$ aftershock) and at least three other $M \approx 6$ earthquakes (Rogers and Horner, 1991). No large subduction zone earthquakes have occurred along the west coast of Canada historically. The geologic record indicates that great earthquakes have occurred off Vancouver Island, with a recurrence interval of about $600 \pm 170$ years (Adams, 1990). The last great Cascadia subduction zone earthquake occurred about 300 years ago, in 1700 (Satake et al., 1996).
The Canadian earthquake catalog is divided into 2 regionalized catalogs, western and eastern (intraplate) Canada.

The catalog used for the hazard map calculations terminates with 1990 in Eastern Canada and 1991 in Western Canada. The lower bound magnitude for earthquakes included in the cata$\operatorname{logs}$ is 2.7. All magnitudes were converted to moment magnitude $(\boldsymbol{M})$; in most cases, the magnitudes in the original catalogs were considered to be equivalent to $M$ (Adams et al., 1996). 


\subsection{Source characterization}

Canada uses the traditional approach to source characterization: delineate source zones based on historic seismicity and/or tectonic provinces (Cornell, 1968). Several experts delineated seismic source zones based on mapped seismicity and seismotectonic information. All of the expert opinions were consolidated into two seismic zone models spanning Canada. One model, named the «H» (for «historical») model, has smaller source zones drawn around historical seismicity clusters in Eastern Canada (fig. 3). The other model, named the «R» (for «regional») model, has larger source zones drawn based on geologic controls in Eastern Canada (fig. 4). The two models differ little in Western Canada, where the seismic zones have been drawn based on a combination of mapped seismicity and known sources (Basham et al., 1997).

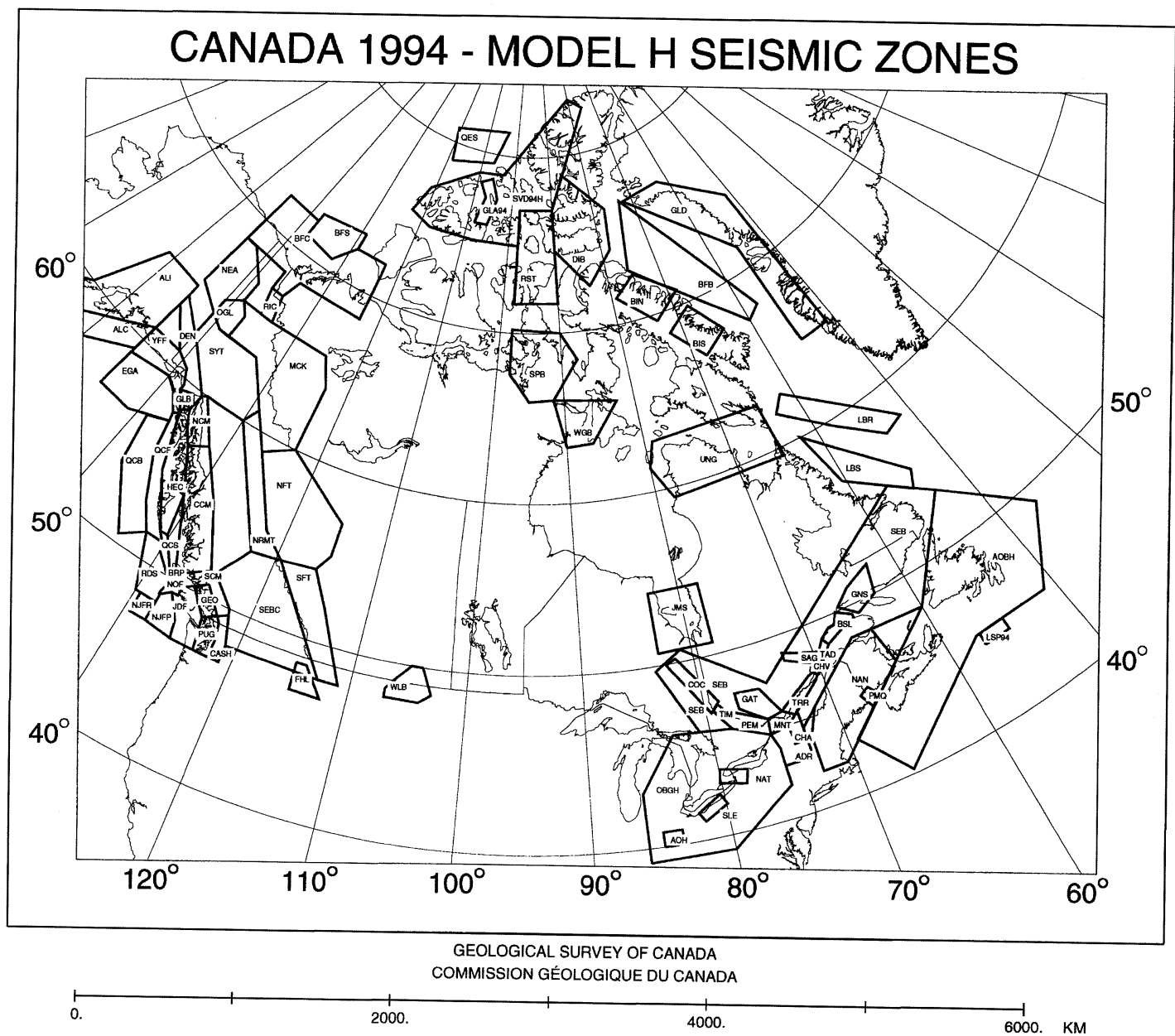

Fig. 3. An example of source zones used in probabilistic seismic hazard assessment. The model «H» seismic source zones of Canada reflect the historic distribution of earthquakes in Eastern Canada and the historic distribution plus geologic input in Western Canada. (Figure taken from Adams et al., 1996). 

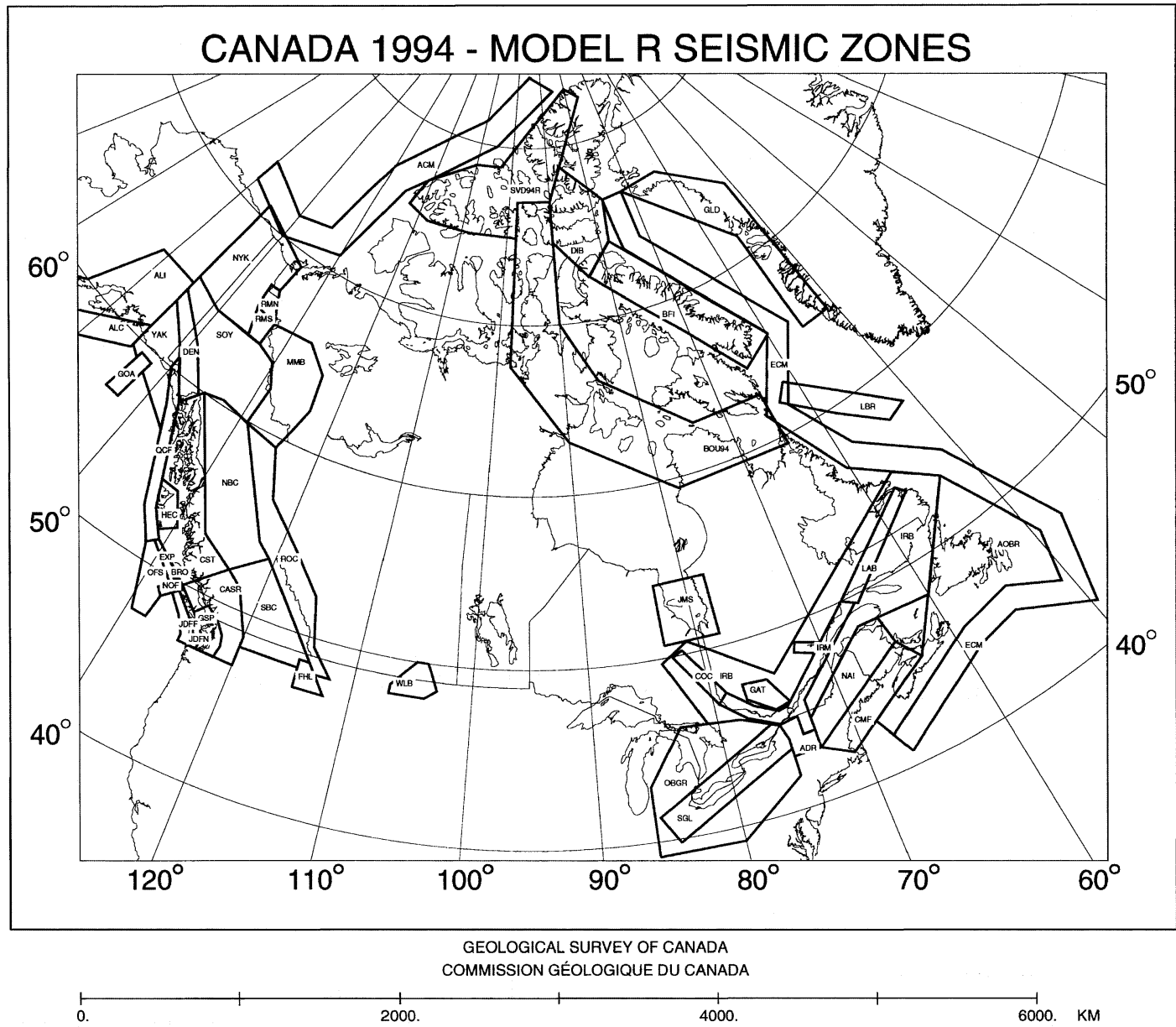

Fig. 4. The «R» seismic source zones model of Canada reflects known geologic inputs across Canada. The zones are generally larger than the model «H» source zones (see fig. 3). (Figure taken from Adams et al., 1996).

The Canadian hazard map incorporates a scenario earthquake to calculate the hazard from a great Cascadian subduction zone earthquake. They assume that the northern portion of the subduction zone could rupture in an $\boldsymbol{M} 8.2$ earthquake. Details of the Canadian seismic source zones and Cascadia scenario earthquake may be found in Adams et al. (1996) or on the WWW (http://www.seismo.nrcan.gc.ca).

\subsection{Strong ground motion relationships}

The current Canadian seismic hazard maps differ only slightly from their predecessors in their reference site condition and attenuation relationships. Instead of «rock or firm soil», the reference site condition for the hazard maps of Canada is «average shear wave velocity of 360 to $750 \mathrm{~m} / \mathrm{s}$ averaged over the top $30 \mathrm{~m}$. 
This corresponds to class B of the Boore et al. (1997) classification scheme, class $\mathrm{C}$ of the National Earthquake Hazard Reduction Program (NEHRP; 1994) classification scheme, and «soft rock» or «firm soil» in all other schemes.

Ground motions were calculated using tectonically appropriate strong ground motion attenuation relationships. Ground motions for Eastern Canada (intraplate) were estimated using the relationships developed by Atkinson and Boore (1995) modified to account for unexpectedly-large short period motion like that in the records from the 1988 Saguenay earthquake (Atkinson, 1995). For Western Canada, ground motion from crustal earthquakes was estimated using relationships developed by Boore et al. (1997). Ground motion from subduction zone and deep intraplate earthquakes was estimated using relationships developed by Crouse (1991). The Crouse (1991) relationships were developed for rock sites, so Canadian scientists modified them to class B soil by adding a period dependent constant derived from the soil terms of Boore et al. (1997). Details of the relationships and the weighting schemes may be found in various publications (Adams et al., 1996; Basham et al., 1997) or on the WWW.

\subsection{Hazard computation method}

The seismic hazard values for a $0.1^{\circ}$ by $0.1^{\circ}$ grid across Canada were calculated using the Cornell (1968) methodology, as applied by McGuire (1993). McGuire's program, FRISK88, allows a range of values for input parameters to account for multiple hypotheses and computation of uncertainty in the resultant hazard values. FRISK88 also allows explicit inclusion of aleatory (randomness) and epistemic (modeling) uncertainties on model parameters. For each of the ground motions mapped, three contributing hazard maps were produced, one for each source zone model ( $\mathrm{H}$ and $\mathrm{R}$ ) and one for a scenario Cascadia earthquake. Each final map was assembled using a «robust» combination method: the three maps were compared point by point, and the largest value at each point was the value selected for the map. This method provides highest hazard values in areas of highest seismicity and lowest, but non-zero, hazard values in areas that currently are aseismic but geologically likely to have future large earthquakes. Details of the method may be found in several publications (McGuire, 1993; Adams et al., 1996; Basham et al., 1997).

\subsection{Results and discussion}

The seismic hazard map of Canada included herein (fig. 8) depicts the median PGA with a $10 \%$ probability of exceedance in 50 years $(5 \%$ of critical damping). The highest seismic hazard values are along the plate boundary region of Western Canada, corresponding to high levels of seismicity and the possible Cascadia scenario earthquake. Areas of relatively high seismicity and/or active faulting (i.e., Southeastern Canada, the Yukon/Northwest Territories, and along the Arctic margin) are the areas of relatively high seismic hazard. Most of Canada has a relatively low seismic hazard, similar to that of other intraplate regions.

Both epistemic (statistical or modeling variations) and aleatory (randomness) uncertainty were explicitly included in the Canadian hazard (McGuire, 1993; Adams et al., 1996). The difference between the median hazard values mapped and the first standard deviation is roughly a factor of $2.0 \pm 50 \%$ for most of the Canadian sites (Adams et al., 1996).

The user communities in Canada have responded very positively to the current seismic hazard maps. The Canadian National Committee on Earthquake Engineering (CANCEE) has accepted these hazard estimates and made recommendations as to their use in developing seismic provisions for the next edition of the $\mathrm{Na}$ tional Building Code of Canada (NBCC). Improvements in future maps will involve inclusion of multiple scenario events for Cascadia and updated regionally appropriate attenuation functions, as well as increases in the amount and bandwidth of recorded earthquake data.

\section{Caribbean}

Although hampered by very uneven station coverage and imprecise magnitudes, various re- 
searchers have published probabilistic seismic hazard maps of islands or regions of the Caribbean. Pereira and Gay (1978) computed hazard maps for Trinidad, Tobago, and Jamaica. Taylor et al. (1978) extended this work to include the Lesser Antilles. After improving the catalog as much as possible, Shepherd and Aspinall (1983) produced an improved hazard map for Trinidad and Tobago. McQueen (1997) produced seismic hazard maps of the Caribbean using three different methods: the Cornell (1968) method, an extreme values method, and the historic parametric method described below. All three methods gave similar results, but McQueen (1997) concluded that the historic parametric method was more stable. The Caribbean seismic hazard map included herein is the first systematic, detailed regional seismic hazard map (McQueen, 1997; Shepherd et al., 1997).

\subsection{Seismicity}

Seismicity in the Caribbean is concentrated along the Caribbean/South American/North
American (and associated smaller) plate boundaries (fig. 5). The Caribbean plate is overriding the North and South American plates on the east. On the west, the Cocos plate is subducting beneath the Caribbean plate. The north and south boundaries of the Caribbean plate are complicated, multiple transform faults.

The historical catalog for the region begins in 1532. The instrumental recording of earthquakes began in the early 20 th century, but the deployment of a regional radio-linked seismograph network occurred in 1976 (Shepherd, 1993). Seismicity recorded in the Caribbean region is concentrated along the Antilles arc, from Hispaniola to Trinidad (fig. 5), where the Caribbean plate is overriding the North and South American plates. Most of the large and moderate earthquakes have been shallow intraplate earthquakes near the plate boundaries, although some researchers have interpreted a few large earthquakes as plate interface events (Dewey and Suárez, 1991).

All magnitudes were converted to moment magnitude $(\boldsymbol{M})$ through a multi-step process (Tanner and Shepherd, 1997). As a first step in

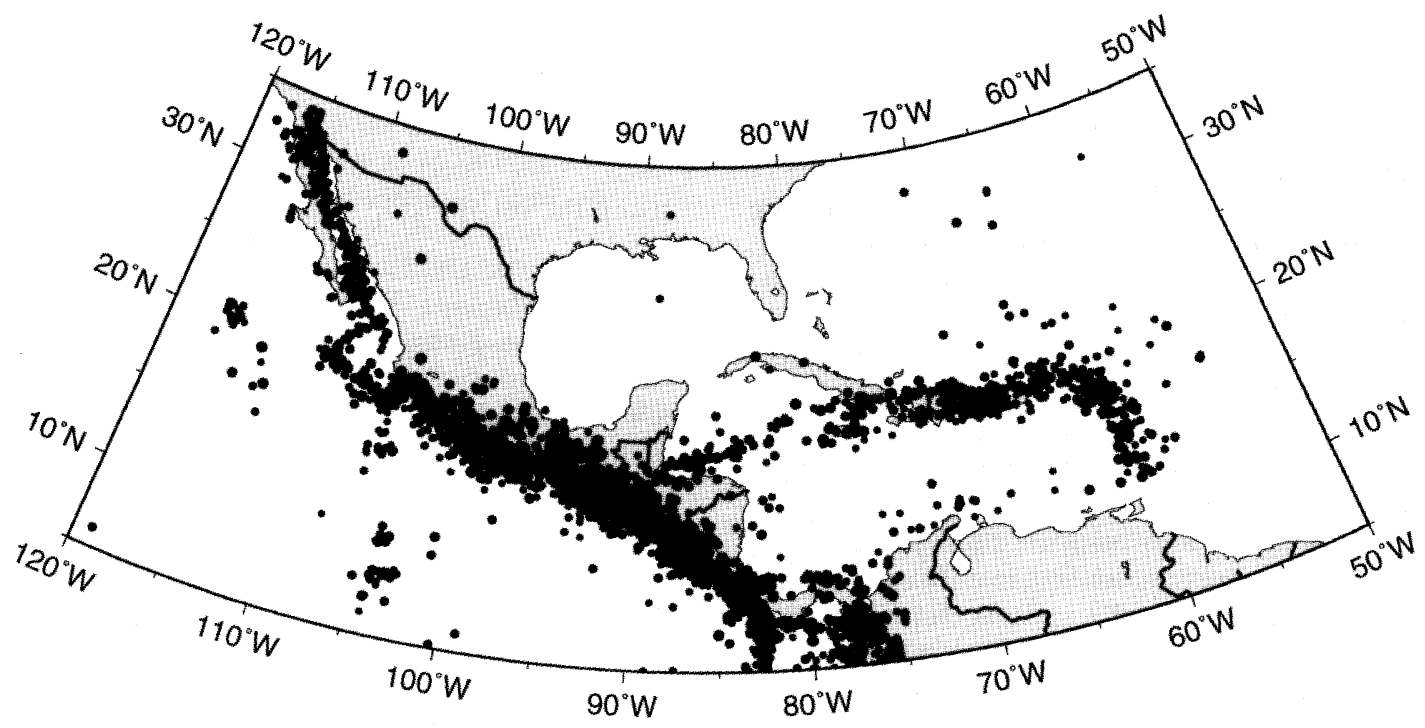

Fig. 5. The locations of damaging earthquakes used to determine the seismic hazard in México, Central America, and the Caribbean. Earthquakes with $\boldsymbol{M} \geq 4.6$ that occurred during the years 1900 through 1994 are plotted. Symbol sizes correspond to $\boldsymbol{M}$. 
their conversion scheme, Tanner and Shepherd (1997) obtained the seismic moment $\left(M_{0}\right)$ of as many of the earthquakes in the catalog as possible. For most of the large earthquakes that occurred prior to the 1980 's, $M_{0}$ has been derived from the relationship

$$
M_{0}=\mu A d
$$

where $\mu$ is the shear modulus (rigidity), $A$ is the area of the fault plane, and $d$ is the average slip during the earthquake (Aki and Richards, 1980). Tanner and Shepherd (1997) then converted $M_{0}$ to $\boldsymbol{M}$ using the relationship

$$
\boldsymbol{M}=2 / 3 \log M_{0}-10.73
$$

derived by Kanamori (1977). The hierarchical scheme developed by Tanner and Shepherd (1997) to assign $\boldsymbol{M}$ values to all the earthquakes in the catalog is:

- $\boldsymbol{M}$ calculated from $M_{0}$, where $M_{0}$ was determined directly from the Aki and Richards (1980) relationship.

- $M$ calculated from $M_{0}$, where $M_{0}$ was determined directly from digital, broadband seismic records.

- $\boldsymbol{M}$ from $M_{0}$, where $M_{0}$ was taken directly from the Harvard University CMT catalog.

- $\boldsymbol{M} \approx M_{S}$ where $M_{S}$ has been reliably determined for $M_{S}>6.6$ and $M=2 / 3 M_{S}+2.34$ for $M_{s} \leq 6.6$.

- $\boldsymbol{M}$ calculated from $m_{b}$ through a two-step process of first converting $m_{b}$ to $M_{s}$ using $M_{s}=1.74 m_{b}-3.95$, then using one of the relationships given above.

- $\boldsymbol{M}$ calculated from other magnitude scales through a two-step process of first converting the other magnitude to $M_{S}$ using one of several known relationships, then using one of the relationships given above.

Any earthquakes with magnitudes that could not be converted to $\boldsymbol{M}$ using the above hierarchy were excluded from the catalog. The catalog used for the hazard map calculations contained all earthquakes with $\boldsymbol{M} \geq 4$ that occurred between 1900 and 1994. The catalog may be considered complete at three levels: $\boldsymbol{M} \geq 7.0$ for $1900-1994 ; \boldsymbol{M} \geq 6.5$ for 1938-1994; and $\boldsymbol{M} \geq 4.3$ for 1964-1994.

\subsection{Source characterization}

Shepherd et al. (1997) chose the Historic Parametric method (described below) to generate seismic hazard maps of the Caribbean. Thus, the earthquake catalog for the Caribbean served as the source characterization for the seismic hazard map. No geologic information was used. No source zones were drawn.

\subsection{Strong ground motion relationships}

The reference site condition for the hazard map of the Caribbean is «rock». This corresponds to class A of the Boore et al. (1993) classification scheme, class B of the National Earthquake Hazard Reduction Program (NEHRP, 1994) classification scheme, and «rock» or «hard rock» in all other schemes.

PGA was calculated using two strong ground motion attenuation relationships. PGA from earthquakes shallower than $15 \mathrm{~km}$ was estimated using the relationship

$$
\begin{gathered}
\log A=-1.229+0.227 \boldsymbol{M}- \\
-\log \left(D^{2}+44.225\right)^{0.5}-0.0023\left(D^{2}+44.225\right)^{0.5}
\end{gathered}
$$

where $D$ is the distance to the rupture and $\boldsymbol{M}$ is moment magnitude (Joyner and Boore, 1993). For all other earthquakes, PGA was estimated using the relationship

$$
\begin{gathered}
\ln A=5.347+0.5 M- \\
-0.85 \ln (D+\exp (0.463 M))
\end{gathered}
$$

where $D$ is the distance to the rupture, and $\boldsymbol{M}$ is moment magnitude (Woodward-Clyde, 1982).

\subsection{Hazard computation method}

Seismic hazard values for a $0.5^{\circ}$ by $0.5^{\circ}$ grid across the Caribbean were calculated using the historic parametric method (Veneziano et al., 1984; McGuire, 1993), as applied by Tanner and Shepherd (1997). The first step is the devel- 
opment of a uniform earthquake catalog for the region. Next, appropriate attenuation functions are identified or developed. Estimates of ground motion from every earthquake in the catalog are calculated at every site in the region based on the chosen attenuation function(s). Return periods for exceedance of a range of values of ground motion are tabulated, and curves are fit to these data. The curves are extrapolated to estimate the value of the ground motion (in this case, PGA) for the return period of interest (approximately 475 years) at each site. Details of the method may be found in several publications (Veneziano et al., 1984; McGuire, 1993; Tanner and Shepherd, 1997).

\subsection{Results and discussion}

The seismic hazard map of the Caribbean depicts the median PGA with a $10 \%$ probability of exceedance in 50 years (return period of 475 years). The $0.5^{\circ}$ by $0.5^{\circ}$ grid of calculated values was interpolated and resampled to a $0.1^{\circ}$ by $0.1^{\circ}$ grid using GMT software (Wessel and Smith, 1995). The PGA seismic hazard map of the Caribbean is included fig. 8. The highest seismic hazard values are in the Dominican Republic-Virgin Islands-Leeward Islands and Trinidad and Tobago. Both these regions of the Antilles arc are where the Eastern Caribbean plate boundary is complicated (fig. 1) and transitional, including large subduction and transform faults.

Uncertainty was explicitly included in the Caribbean hazard calculations. All input parameters were assumed to be normally distributed except attenuation and depth, which were assumed to be log-normally distributed. The software developed by Tanner and Shepherd (1997) used a pseudo-random number generator to scale the standard deviations assigned to each parameter. Median PGA values at each site were calculated after a minimum of 100 iterations through the range of parameter variations.

The user communities in the Caribbean have responded very positively to this first systematic regional seismic hazard map. Improvements in future maps will involve inclusion of scenario events for the Caribbean, updated regionally appropriate ground motion attenuation relationships, increases in the amount and bandwidth of recorded earthquake data, and the production of several SA maps.

\section{Central America}

Various researchers have published probabilistic seismic hazard maps of countries or regions of Central America. Mortgat et al. (1977) published the first hazard map of Costa Rica. Local seismic hazard investigations were performed for parts of El Salvador as a result of the 1986 earthquake $\left(M_{S}=5.4,1500\right.$ deaths), Nicaragua as a result of the 1972 earthquake $\left(M_{s}=6.2,11000\right.$ deaths), and Guatemala as a result of the 1976 earthquake $\left(M_{S}=7.5,23000\right.$ deaths), but these are unpublished. During the 1990's, the countries of Costa Rica, El Salvador, Guatemala, Honduras, Nicaragua, and Panama formed the Committee for the Prevention of Natural Disasters (CEPREDENAC) to coordinate their hazards research, including seismic hazards. CEPREDENAC has fostered cooperative network deployment and studies of seismicity and hazards with institutions in Denmark, Sweden, and Norway. Similarly, through the Pan-American Institute of Geography and History (PAIGH), the CEPREDENAC countries and Belize, under the leadership of the Escuela Centroamericana de Geologia of the Universidad de Costa Rica (ECG-UCR), have cooperated with researchers from Canada and Great Britain to produce two seismic hazard maps of the region. One hazard map was produced using the Cornell (1968) method (Montero et al., 1997) and the other using the historic parametric method (Tanner and Shepherd, 1997). The seismic hazard map of Central America included in this report is the map produced under the auspices of PAIGH and using the historic parametric method.

\subsection{Seismicity}

Seismicity in Central America is concentrated along the North American/South American/ Caribbean /Cocos/Nazca (and associated small- 
er) plate boundaries (fig. 5). The historical catalog for the region begins in 1516 . The instrumental recording of earthquakes began in 1882 , but the deployment of national seismograph networks in the countries of Central America occurred in the 1970's (Rojas et al., 1993). The Cocos/Caribbean plate interface is steeply dipping beneath Central America from Guatemala to Northern Costa Rica, with interface earthquakes as large as $\boldsymbol{M} 8$ and as deep as $200 \mathrm{~km}$ (Dewey and Suárez, 1991). The interface shallows towards the Cocos/Nazca/Caribbean triple junction, with deep-to-intermediate earthquakes disappearing altogether. The most destructive earthquakes in much of Central America have been shallow, moderate ( $\boldsymbol{M} 5$ to 6.5), intraplate, strike-slip earthquakes (Dewey and Suárez, 1991).

The catalog used for the hazard map calculations contained all earthquakes with $\boldsymbol{M}>4.0$ that occurred between 1900 and 1994. All magnitudes were converted to moment magnitude $(\boldsymbol{M})$ through the multi-step process described in the Caribbean section of this report. The catalog may be considered complete at three levels: $\boldsymbol{M} \geq 7.0$ for 1900-1994; $\boldsymbol{M} \geq 6.5$ for 1938-1994; and $\boldsymbol{M} \geq 4.3$ for 1964-1994 (Tanner and Shepherd, 1997).

\subsection{Source characterization}

The PAIGH Project Steering Committee chose the historic parametric method (described in the Caribbean section of this report) to generate this seismic hazard map of Central America. Thus, the earthquake catalog for the region served as the source characterization for the seismic hazard map. No geologic information was used. No source zones were drawn.

\subsection{Strong ground motion relationships}

The reference site condition for the hazard map of Central America is «rock». This corresponds to class A of the Boore et al. (1993) classification scheme, class B of the National Earthquake Hazard Reduction Program (NEHRP, 1994) classification scheme, and «rock» or «hard rock» in all other schemes.
PGA was calculated using two strong ground motion attenuation relationships. PGA from earthquakes shallower than $15 \mathrm{~km}$ was estimated using the relationship

$$
\begin{gathered}
\log A=-1.229+0.227 \boldsymbol{M}- \\
-\log \left(D^{2}+44.225\right)^{0.5}-0.0023\left(D^{2}+44.225\right)^{0.5}
\end{gathered}
$$

where $D$ is the distance to the rupture and $\boldsymbol{M}$ is moment magnitude (Joyner and Boore, 1993). For all other earthquakes, PGA was estimated using the relationship

$$
\begin{gathered}
\ln A=-1.687+0.553 M- \\
-0.537 \ln R-0.00302 R
\end{gathered}
$$

where $R$ is either the depth to the hypocenter if $R<\mathrm{RD}$ (defined in the corresponding section of the México portion of this report) or the distance from the point to the edge of the rupture zone if $R \geq \mathrm{RD}$, and $\boldsymbol{M}$ is moment magnitude (Climent et al., 1994).

\subsection{Hazard computation method}

The seismic hazard values for a $0.5^{\circ}$ by $0.5^{\circ}$ grid across Central America were calculated using the historic parametric method (Veneziano et al., 1984; McGuire, 1993), as applied by Tanner and Shepherd (1997). This method is described in the Caribbean section of this report.

\subsection{Results and discussion}

The seismic hazard map of Central America depicts the median PGA with a $10 \%$ probability of exceedance in 50 years. The PGA seismic hazard map of Central America is included fig. 8 . The $0.5^{\circ}$ by $0.5^{\circ}$ grid of calculated values were interpolated and resampled to a $0.1^{\circ}$ by $0.1^{\circ}$ grid using GMT software (Wessel and Smith, 1995). The highest seismic hazard values are along the west coast of Central America, coincident with the subduction of the Cocos plate beneath the Caribbean plate. The highest hazard values are due to the possibilities of the repeat of any of the medium-to-large damaging historical earthquakes (1972, 1976, and 1986) along the Pacific coast of Central America. 
Montero et al. (1997) computed a map of PGA with a $10 \%$ chance of exceedance in 50 years for Central America using the Cornell (1968) method, as applied by Dahle (1994). Although the results of the two methods are generally similar, the hazard calculated using the Cornell (1968) method is lower and more broadly distributed than that using the historic parametric method. Both research groups used the same attenuation relationships in their calculations, and any differences in their catalogs were minor. Thus, the differences between the two sets of results must be due largely to the difference in source characterization. The use of source zones (Cornell method) distributes ground motions throughout each zone. The historic parametric method assigns the largest earthquake ground motions to the epicentral regions of earthquakes in the catalog.

Uncertainty was explicitly included in Central America hazard calculations. All input parameters were assumed to be normally distributed except attenuation and depth, which were assumed to be log-normally distributed. The software developed by Tanner and Shepherd (1997) uses a pseudo-random number generator to scale the standard deviations assigned to each parameter. Median PGA values at each site are then calculated after a minimum of 100 iterations through the range of parameter variations.

The user communities in Central America have responded very positively to this first systematic regional seismic hazard map. Improvements in future maps will involve inclusion of scenario events for Central America, updated regionally appropriate ground motion relationships, increases in the amount and bandwidth of recorded earthquake data, and the production of several SA maps.

\section{México}

Researchers in México have been publishing probabilistic seismic hazard maps since 1968 (Esteva, 1970). Since then, various seismic hazard maps have been produced for regions and/or cities within México as they were needed. The seismic hazard map of México included herein is the first systematic, detailed national seismic hazard map (Zúñiga et al., 1997). Complete documentation describing the procedures and input data used to make the seismic hazard map of México may be found in Zúñiga et al. (1997).

\subsection{Seismicity}

Seismicity in México is concentrated along the Pacific/Cocos/Caribbean/North American plate boundaries (off the south and west coasts and Baja California, fig. 5). The historical catalog for México begins in 1475 (Zúñiga et al., 1997). The instrumental recording of earthquakes in México began in the 1930's, but the major expansion of a national seismograph network occurred in the 1960's. The largest earthquakes $(\boldsymbol{M} \geq 7.5)$ in México have occurred along the North American/Cocos (and the small Rivera) plate boundaries. The plate interface(s) dip shallowly and the large earthquakes occur at depths $\leq 30 \mathrm{~km}$ (Dewey and Suárez, 1991). The Pacific/North American plate boundary is an en echelon transform fault boundary with smaller, less frequent earthquakes.

The catalog used for the hazard map calculations contained 6350 earthquakes that occurred between 1900 and 1994. All magnitudes were converted to moment magnitude $(\boldsymbol{M})$ through the multi-step process described in the Caribbean section of this report. The catalog may be considered complete at three levels: $\boldsymbol{M} \geq 7.0$ for 1900-1994; $\boldsymbol{M} \geq 6.5$ for 1938-1994; and $\boldsymbol{M} \geq 4.3$ for 1964-1994.

\subsection{Source characterization}

México used the traditional approach to source characterization: delineate source zones based on historic seismicity and/or tectonic provinces (Cornell, 1968). Researchers divided México into 19 seismotectonic regions based on earthquake locations, type of faulting, and tectonic characteristics. These regions were subdivided into smaller, rectangular regions for the hazard calculations. Details of the Méxican seismic source zones may be found in Zúñiga $e t$ al. (1997). 


\subsection{Strong ground motion relationships}

The reference site condition for the hazard map of México is «rock». This corresponds to class A of the Boore et al. (1993) classification scheme, class B of the National Earthquake Hazard Reduction Program (NEHRP, 1994) classification scheme, and «rock» or «hard rock» in all other schemes.

Ground motions were calculated using tectonically appropriate strong ground motion attenuation relationships. Ground motions for the relatively few shallow earthquakes that occur in Northern México (away from the plate boundary region) and the far-field of subduction events were estimated using the PGA relationship developed by Joyner and Boore (1981). For subduction zone earthquakes, near-field ground motion was estimated using a PGA relationship developed by Dr. M. Ordaz, of Universidad Nacional Autónoma de México (UNAM). PGA from deep intraplate earthquakes was estimated using the theoretical model developed by Rosenblueth et al. (1989).

The Ordaz PGA attenuation relationship avoids rapid attenuation of ground motion near the earthquake epicenter through explicit inclusion of the half-width (RD) of the rupture zone (Singh et al., 1982)

$$
\mathrm{RD}=0.5\left(10^{M-4}\right)^{1 / 2}
$$

where $\mathrm{RD}=$ distance from the epicenter to the edge of the rupture zone, and $\boldsymbol{M}$ is the moment magnitude of the earthquake. RD (the near field) was limited to a maximum value of $37 \mathrm{~km}$ for the calculation of hazard. PGA at a point is then calculated by

$$
\mathrm{PGA}=1.76+0.3 M-\log D-0.0031 D
$$

where $\boldsymbol{M}$ is the moment magnitude of the earthquake, $D$ is either the depth to the hypocenter if $D<\mathrm{RD}$ or the distance from the point to the edge of the rupture zone if $D \geq \mathrm{RD}$, and PGA is in gal. Maximum PGA values were limited to 526 gal for $\boldsymbol{M} \geq 8$. México is unique in the Americas in that the digital Guerrero seismic array recorded on-scale strong-motion data from 146 earthquakes, including the 1985 M 8.0 earth- quake (Anderson and Lei, 1994). Their data indicate that PGA saturated at about $200 \mathrm{gal}$ $(20 \% \mathrm{~g})$, but attenuated more slowly with distance than assumed in the development of theoretical attenuation curves. Thus, the PGA limit of 526 gal for any one large earthquake is a reasonable compromise between the Guerrero data and PGA values determined globally. Details of the derivation of the relationship may be found in Zúñiga et al. (1997).

\subsection{Hazard computation method}

The seismic hazard values for México were calculated using the general Cornell (1968) approach, as adapted by M. Ordaz. Seismic sources were identified as subduction, intermediate depth, and shallow continental sources. Subduction earthquakes were sub-divided into two categories: those with $\boldsymbol{M}<7$ were assumed to have a Poisson distribution in time and those with $\boldsymbol{M} \geq 7$ were assumed to be «characteristic earthquakes». The occurrence of intermediate and shallow earthquakes was assumed to be Poissonian. Source zone characteristics were estimated using Bayesian statistics. PGA values were calculated for a $0.5^{\circ}$ by $0.5^{\circ}$ grid across México. Details of the method may be found in Zúñiga et al. (1997).

\subsection{Results and discussion}

The seismic hazard map of México (included in fig. 8) depicts the mean PGA with a $10 \%$ probability of exceedance in 50 years (return period 500 years). The highest seismic hazard values are along the plate boundary regions of Southwestern México, where the largest historical earthquakes have occurred (along the Cocos/Caribbean and Rivera/North America subduction zones). These predominantly thrustfaulting large $(\boldsymbol{M} \geq 7.5)$ interface earthquakes have short recurrence intervals (on the order of $30-40$ years) and are shallow. Thus, they pose a high hazard to the coast, as well as to cities further inland situated within sedimentary basins (e.g., México City). The transform faulting plate boundary along which Baja California is 
moving northwest with respect to the rest of México is an en-echelon transform boundary. Thus, the earthquakes, and hazard values, along it are smaller than those along the continuous San Andreas fault to the north, and much smaller than those along the subduction zone boundaries to the south.

Improvements in future seismic hazard maps of México will involve inclusion of scenario events for Central America, updated regionally appropriate ground motion relationships, increases in the amount and bandwidth of recorded earthquake data, and the production of several SA maps.

\section{United States}

The U.S. Geological Survey (USGS) has been publishing national probabilistic seismic hazard maps since 1976. The U.S. maps are used in building codes and by structural engineers, the insurance industry, businesses, emergency services, community planners, and the general public. These maps are updated with new data and/ or methodologies about every five years (e.g., Algermissen and Perkins, 1976; Algermissen et. al., 1982, 1990; Leyendecker et al., 1995). Complete documentation describing the procedures and input data used to make the current seismic hazard maps of the United States may be found in several publications (Frankel, 1995; Frankel et al., 1996, 1997a,b; Petersen et al., 1996; Wesson et al., 1999; Klein et al., 1999), and on the World Wide Web (http://geohazards. cr.usgs.gov/eq/). The suite of U.S. hazard maps depicts probabilistic ground motions (PGA, 0.2 , $0.3,0.5,1.0$, and $2.0 \mathrm{~s}$ spectral acceleration, $5 \%$ damping) with $2 \%, 5 \%$, and $10 \%$ Probabilities of Exceedance (PE) in 50 years (return times of 2373,950 , and 475 years, respectively). Copies of the U.S. maps and documentation may be downloaded or ordered from the World Wide Web (WWW) site.

\subsection{Seismicity}

Seismicity in the United States is concentrated along the North American/Pacific plate boundary (west coast of the contiguous 48 states, the south coast and islands of Alaska), and Southeastern Hawaii. Other areas of active seismicity include the basin and range (Nevada and Eastern California), the intermountain seismic belt (Northern Arizona to the U.S./Canada border), the Pacific Northwest region (Western Washington and Oregon), central Idaho, the New Madrid Seismic zone (Central U.S.), Eastern Tennessee/South Carolina, New England, and Northern New York (fig. 6).

The U.S. earthquake catalog is divided into 4 regionalized catalogs: the western contiguous U.S., the central and eastern contiguous U.S., Alaska, and Hawaii. Complete documentation describing the earthquake catalogs used to make the current seismic hazard maps of the United States may be found in several publications (Mueller et al., 1997; Klein et al., 1999; Mueller et al., 1998). The catalogs and publications may be obtained from the World Wide Web (http://geohazards.cr.usgs.gov/eq/).

All earthquakes in the U.S. catalogs have been assigned either an equivalent moment $(\boldsymbol{M})$ or body-wave $\left(m_{b}^{*}\right)$ magnitude, determined using hierarchical schemes. Foreshocks, aftershocks, documented artificial sources, and duplicate entries were removed using different algorithms. All of these methods are explained in the documentation corresponding to each catalog. The final catalog for the western contiguous U.S. contains 2891 earthquakes with $\boldsymbol{M} \geq 4.0$ that occurred between 1852 and June, 1995. The final catalog for the central and eastern contiguous U.S. contains 2738 earthquakes with $m_{b}^{*} \geq 3.0$ that occurred between 1701 and June 30, 1995. The final catalog for Alaska contains 5282 earthquakes with $M \geq 4.0$ that occurred between 1880 and 1996. The final catalog for Hawaii contains 4989 earthquakes with $M \geq 3.0$ that occurred between 1868 and June, 1997.

\subsection{Source characterization}

The traditional approach to source characterization is to delineate source zones based on historic seismicity and/or tectonic provinces (Cornell, 1968). Although all previous U.S. seis- 


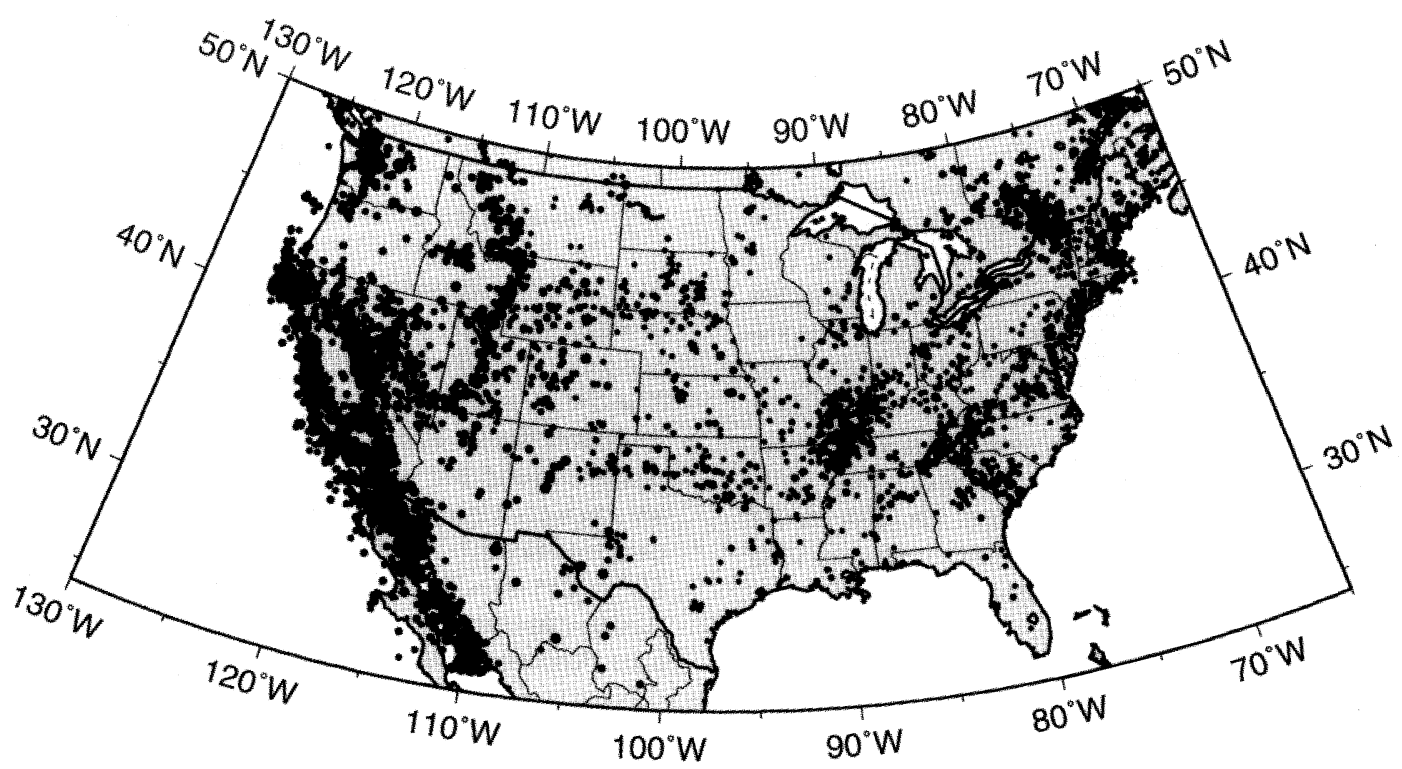

Fig. 6. The locations of damaging earthquakes used to determine the seismic hazard in the contiguous 48 states of the United States. Earthquakes with $\boldsymbol{M} \geq 4.0$ that occurred between 1852 and July, 1995 in the Western U.S. and earthquakes with $m_{b} \geq 3.0$ that occurred between 1701 and July, 1995 are plotted. Symbol size corresponds
to magnitude.

mic hazard maps have used this approach, the U.S. has chosen a different approach for the current generation of hazard maps (Frankel, 1995). The U.S. methodology uses a series of models based on spatially smoothed seismicity to characterize hazard. Different alternative source models were determined for different regions of the U.S., but the philosophy behind the development of each suite of models was the same. First, models that indicate where moderate earthquakes are likely to occur were determined by spatially smoothing known seismicity over appropriate windows of catalog completeness. Then, models that account for repeats of damaging events were determined using catalogs and paleoseismic data where appropriate. Background source zone models were developed to quantify hazard in areas of little to no known seismicity, but with the potential to generate damaging earthquakes. Finally, in regions where seismicity and faults were well-quantified, scenario (and/or characteristic) earthquake models were developed. Details of the U.S. source characterizations may be found in various publications (Frankel, 1995; Frankel et al., 1996, 1997a; Petersen et al., 1996; Wesson et al., 1999; Klein et al., 1999) or on the WWW.

\subsection{Strong ground motion relationships}

The current U.S. maps differ from their predecessors in the reference site condition and attenuation relationships. Instead of «rock», the U.S. maps reference site condition is «average shear wave velocity of $760 \mathrm{~m} / \mathrm{s}$ in the top $30 \mathrm{~m}$ ». This corresponds to the $\mathrm{B} / \mathrm{C}$ boundary of the National Earthquake Hazard Reduction Program (NEHRP, 1994) and the Boore et al. (1997) classification schemes, and «rock» or «firm rock» in all other schemes.

Ground motions were calculated using equally weighted tectonically appropriate strong ground motion attenuation relationships. Ground 
motions for the Central and Eastern U.S. (intraplate) were estimated using the relationships developed by Toro et al. (1997) and Frankel et al. (1996). For the western contiguous U.S., ground motion from crustal earthquakes was estimated using relationships developed by Boore et al. (1997), Sadigh et al. (1997), and Campbell and Bozorgnia (1994). Ground motion from subduction zone earthquakes was estimated using relationships developed by Youngs et al. (1997) and Sadigh et al. (1997). The Youngs et al. (1997) relationships also were used to estimate ground motion from deep $(45 \mathrm{~km})$ intraplate earthquakes. Details of the relationships and the weighting schemes may be found in various publications (Frankel et al., 1996, 1997a; Petersen et al., 1996; Wesson et al., 1999; Klein et al., 1999) or on the WWW.

\subsection{Hazard computation method}

Frankel et al. (1996) developed a new suite of software to calculate the current U.S. seismic hazard maps. The seismic hazard posed by several alternative source models and from scenario (and/or characteristic) earthquakes is calculated, and the final maps are weighted averages of these results. Each regional hazard map was calculated using adaptive weighting schemes to combine the results from each of the models. The regional maps were concatenated to produce the final suite of U.S. hazard maps. Once the Hawaii maps (currently undergoing revision) and documentation are completed, the hazard software and documentation will be prepared for release. Availability will be announced and the programs and documentation will be available via the WWW at http://geohazards. cr.usgs.gov. Details of the method may be found in several publications (Frankel, 1995; Frankel et al., 1996) and the WWW page.

The U.S. approach is based on the assumption that earthquake occurrence is assumed to be Poissonian, with time-independent probability. The mapped values are the mean ground motion values. Hazard values are calculated for a $0.1^{\circ}$ by $0.1^{\circ}$ grid across the Western U.S. and Alaska, a $0.05^{\circ}$ by $0.05^{\circ}$ grid across California, a $0.2^{\circ}$ by $0.2^{\circ}$ grid across the Eastern U.S., and a $0.02^{\circ}$ by $0.02^{\circ}$ grid across Hawaii. After interpolation or resampling, a $0.1^{\circ}$ by $0.1^{\circ}$ grid was obtained for the contiguous U.S.

\subsection{Results and discussion}

The U.S. seismic hazard map included herein depicts PGA with a $10 \%$ probability of exceedance in 50 years (5\% of critical damping). The PGA seismic hazard map of the U.S. is included fig. 8. The highest seismic hazard values are along the plate boundary regions of the western contiguous U.S. and Alaska, and Southeastern Hawaii. The highest hazard values occur along the on-shore portion of the Pacific/North American transform faulting plate boundary, the San Andreas fault (Southern California). Although the historic and pre-historic subduction zone earthquakes of the Pacific Northwest and Alaska are larger $\boldsymbol{M}$ earthquakes than any earthquakes along the San Andreas, the subduction zone faults are tens to hundreds of kilometers offshore and the earthquake hypocenters are intermediate-to-deep. Earthquakes along the San Andreas system are shallow and onshore. Thus, the hazard from them is greater. Areas of relatively high seismicity and/or active faulting (i.e. basin and range, intermountain seismic belt) are the areas of relatively high seismic hazard. Large regions of the Central and Eastern U.S. have a relatively low level of seismic hazard, similar to intraplate Canada.

Uncertainty in the U.S. hazard calculations was estimated using Monte Carlo simulations (Cramer et al., 1996; Frankel et al., 1997b). Parameters related to source characterization (catalog sampling, $b$-values, each alternative model, etc.), ground motion attenuation, and the scenario (or characteristic) earthquakes were varied to create a set of hazard curves for major cities or regions (e.g., Southern California). The map of uncertainties for selected cities in the intraplate U.S. (fig. 7) illustrates that the largest uncertainties correspond to sites with little or no known seismicity. These large uncertainties reflect our lack of knowledge about the potential for damaging earthquakes at or near these sites.

Sensitivity analyses were performed by varying each parameter separately while holding 


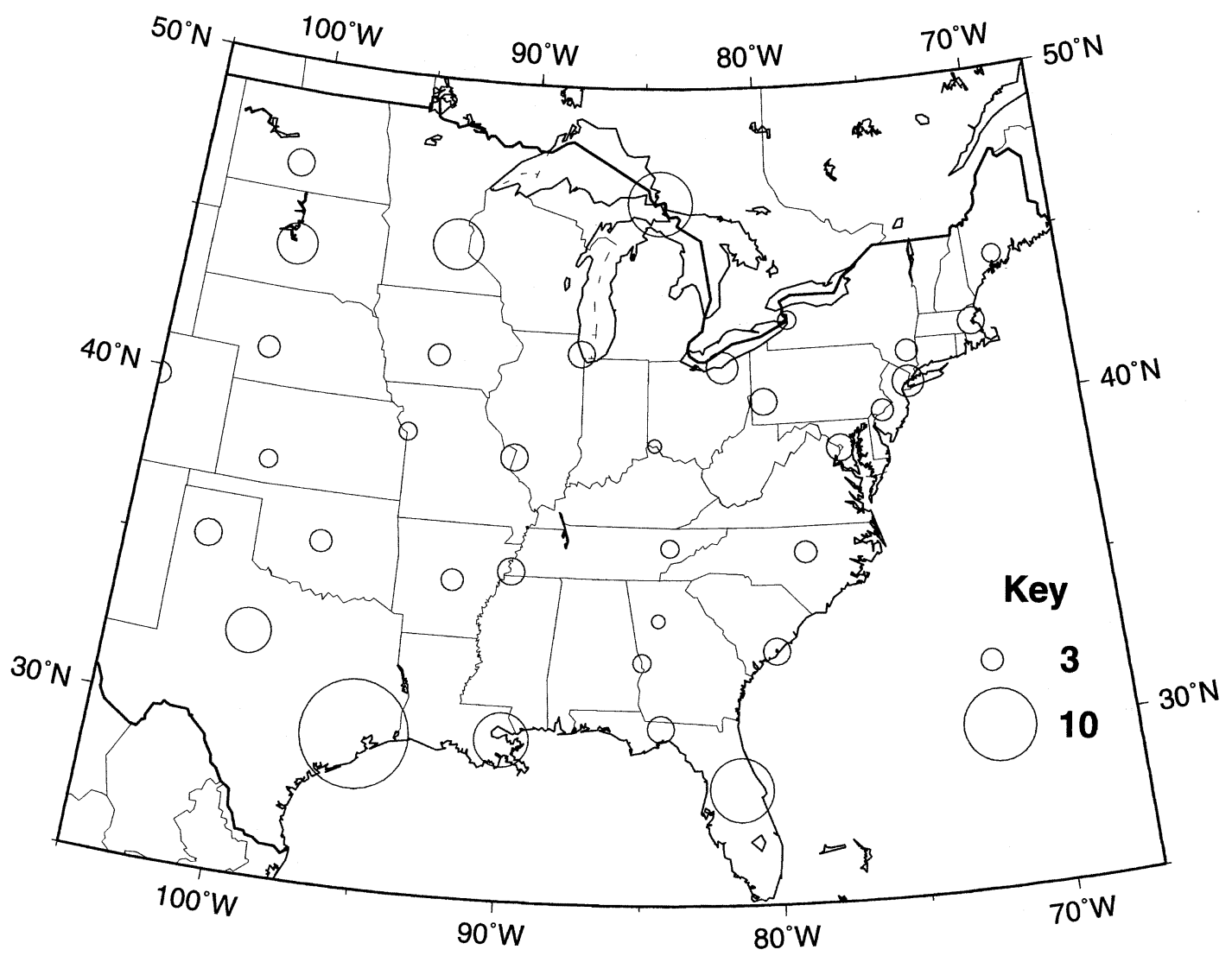

Fig. 7. Uncertainties in the $5 \mathrm{~Hz}$ SA values for selected cities in the intraplate U.S. Uncertainties in the PGA values are comparable. The diameter of each circle is proportional to the ratio of the 85th fractile to the 15th fractile. The ratio varies from about 2.5 to 15 . (Figure taken from Frankel et al., 1997b).

all the others fixed in Monte Carlo simulations (Cramer et al., 1996). The parameters that contribute the most to the uncertainty estimates are the maximum magnitude, magnitude-frequency distribution, and slip rate determined from geologic data and the choice of attenuation relationships (Cramer et al., 1996).

The user communities in the United States have responded very positively to the current U.S. seismic hazard maps. The number one conclusion of an National Center for Earthquake Engineering Research (NCEER) study conducted for the Federal Highway Administration is «(1) new (1996) USGS national ground motion maps provide a substantially more accurate representation of seismic ground motion than earlier maps and are recommended to provide a basis for a new national seismic hazard portrayal for highway facilities design».

Professional engineering and building code organizations have adopted the U.S. maps for inclusion in their updated codes. Improvements in future maps will involve increases in the amount and bandwidth of recorded earthquake data, increases in the amount and availability of strong-motion and structural response data, and three-dimensional wave-propagation modeling. 


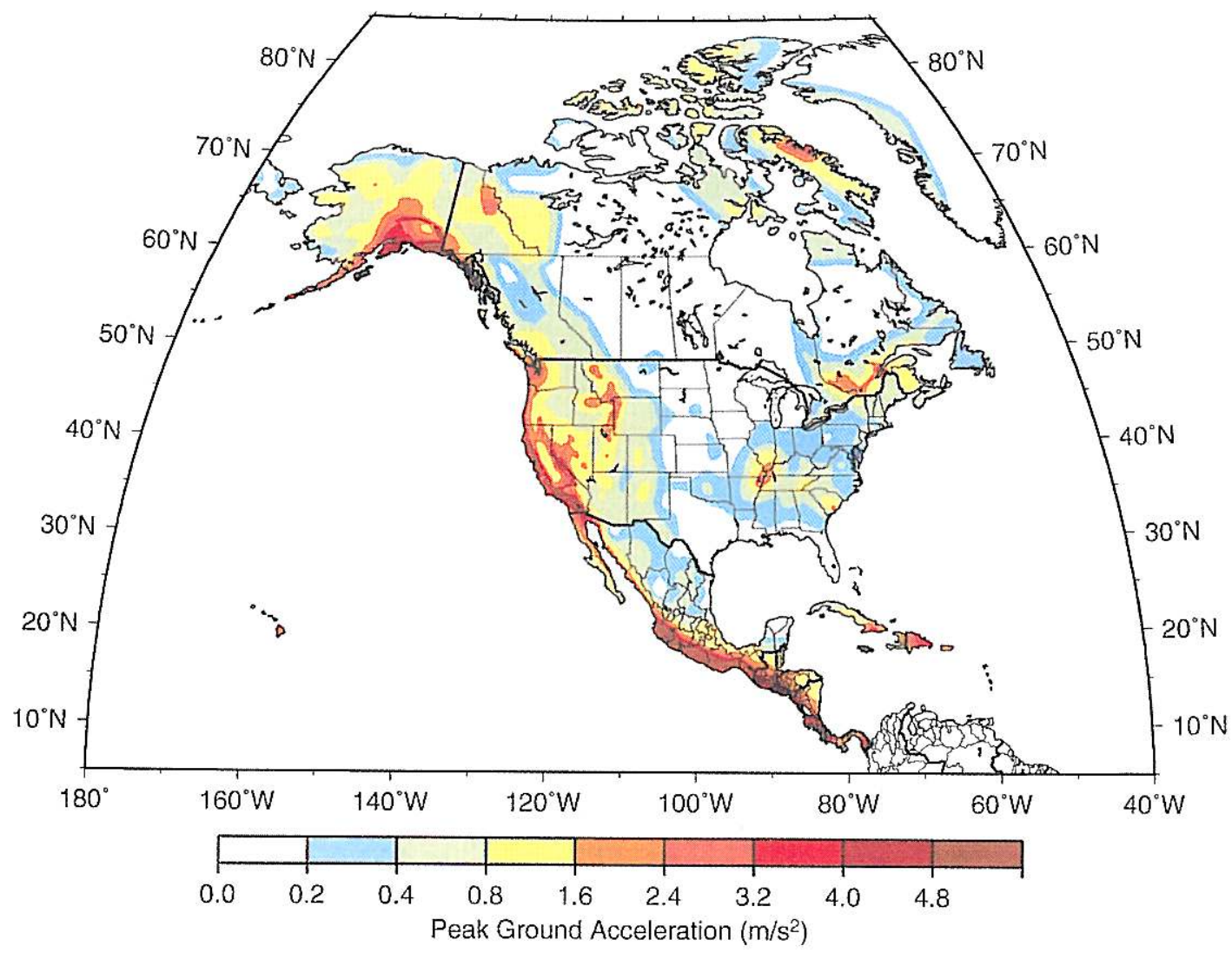

Fig. 8. The seismic hazard map of North and Central America and the Caribbean. PGA with a 10\% chance of exceedance in 50 years is depicted in $\mathrm{m} / \mathrm{s}^{2}$.

\section{Summary}

The seismic hazard map of the North and Central America and the Caribbean depicts PGA with a $10 \%$ chance of exceedance in 50 years. The site classification is rock everywhere except Canada and the United States, which assume rock/firm soil reference ground conditions. PGA calculated for rock/firm soil sites will be larger than PGA calculated for rock sites for a given earthquake. Thus, the PGA values calculated for Canada and the United States are systematically larger ( $\leq 25 \%$ larger) than PGA values calculated for México, Central America, and the Caribbean. The return period for Mex- ico is 500 years. The return period for all other countries is 475 years.

The highest seismic hazard values in North and Central America and the Caribbean generally correspond to areas that have been, or are likely to be, the sites of the largest plate boundary earthquakes. The areas of greatest hazard are along the subduction plate boundaries of Alaska, Central America, the Eastern Caribbean and México, the transform plate boundaries of the Northern Caribbean and Western U.S., and the southeast coast of Hawaii. Although Hawaii is not near a plate boundary, it is a 'hot-spot', where whole-plate (rather than intraplate) tectonic processes dominate. 
Although the energy release in large subduction zone earthquakes is much greater than the energy release in transform fault (strikeslip) earthquakes, the highest hazard value calculated in North and Central America and the Caribbean is in Southern California (U.S.), along the San Andreas fault (even when reduced to match the site classification of other countries). Large subduction zone earthquakes are deep (many tens to hundreds of kilometers) and the subduction zones along North and Central America are tens to hundreds of kilometers offshore. Thus, energy released in a large subduction zone earthquake has begun to attenuate before it reaches onshore population centers. Earthquakes along the San Andreas fault (and transform faults in general) are shallow $(<20 \mathrm{~km})$ and often involve surface rupture. The San Andreas fault is onshore for much of its length, and passes through Southern California. Thus, energy released in a large San Andreas fault earthquake passes through population centers immediately, producing a higher shaking hazard.

\section{Acknowledgements}

This seismic hazard map of North and Central America and the Caribbean is the result of decades of work and the contributions of hundreds of scientists and technical personnel, as well as universities and public and private agencies and organizations, throughout North and Central America and the Caribbean. Although it is impractical to name, I am grateful to every contributor. In particular, I want to thank Jim Tanner for his patience, counsel, and good nature through it all. John Adams, Art Frankel, Stephen Halchuk, Chuck Mueller, and Ramon Zúñiga have been wonderful cooperators - thank you! Thanks to P. Wessel and W.H.F. Smith for developing GMT, which I used to produce every figure in this text. The principle authors (and their affiliations) of the maps combined to produce this map are listed under «Contact information» (below). Many more contributors are listed in the «References» section.

\section{Contact information}

\section{Canada}

J. Adams, D.H. Weichert, S. Halchuk and P. Basham Geological Survey of Canada

Contact:

John Adams (adams@ seismo.nrcan.gc.ca)

Stephen Halchuk (halchuk@ seismo.nrcan.gc.ca)

Geological Survey of Canada

1 Observatory Crescent

Ottawa, ON, K1A 0Y3, Canada

\section{Central America and the Caribbean}

Walter Montero P., Giovanni Peraldo H. and Wilfredo Rojas Q.

Universidad de Costa Rica

J.G. Tanner', J.B. Shepherd', C.M. McQueen ${ }^{2}$

and L.L. Lynch ${ }^{3}$

University of Western Ontario ${ }^{1}$, University

of Lancaster ${ }^{2}$ and University of the West Indies ${ }^{3}$

Contact:

Walter Montero P. (wmontero@ cariari.ucr.ac.cr)

Escuela Centroamericana de Geologia

Universidad de Costa Rica

Apartado 35-2060

San José, Costa Rica

James G. Tanner (jtanner@execulink.com)

IPGH

R.R. \#1

Union, ON, NOL 2L0, Canada

\section{Mexico}

R. Zúñiga, G. Suárez, M. Ordaz and V. García-Acosta Universidad Nacional Autonoma De Mexico

Contact:

Ramon Zúñiga (ramon@ollin.igeofcu.unam.mx)

Instituto de Geofisica

UNAM

Cd. Universitaria

Coyoacán

México 04510, D.F., México

\section{United States}

A. Frankel, R. Wesson, C. Mueller, F. Klein, T. Barnhard, D. Perkins, E.V. Leyendecker, N. Dickman, S. Harmsen, S. Hanson and M. Hopper United States Geological Survey

Contact:

Art Frankel (afrankel@usgs.gov)

USGS

MS 966 Box 25046

Denver, CO 80225, U.S.A. 


\section{REFERENCES}

ADAMS, J. (1990): Paleoseismicity of the Cascadian subduction zone - evidence from turbidites off the OregonWashington margin, Tectonics, 9, 569-583.

ADAMS, J., D.H. WEICHERT, S. HALCHUK and P. BASHAM (1996): Trial seismic hazard maps of Canada - 1995: final values for selected Canadian cities, Geol. Surv. Can. Open File 3283, p. 97.

AKI, K. and P.G. RICHARDS (1980): Quantitative Seismology: Theory and Methods, I (W.H. Freeman, San Francisco), pp. 557.

Algermissen, S.T. and D.M. PERKINS (1976): A probabilistic estimate of maximum acceleration in rock in the contiguous United States, U.S. Geol. Surv. OpenFile Rep. 76-416, p. 45, 3 plates.

Algermissen, S.T., D.M. Perkins, P.C. Thenhaus, S.L. HANSON and B.L. BENDER (1982): Probabilistic estimates of maximum acceleration and velocity in rock in the contiguous United States, U.S. Geol. Surv. OpenFile Rep. 82-1033, p. 99, 6 plates.

Algermissen, S.T., D.M. Perkins, P.C. Thenhaus, S.L. HANSON and B.L. BENDER (1990): Probabilistic earthquake acceleration and velocity maps for the United States and Puerto Rico, U.S. Geol. Surv. Map MF-2120, 2 sheets, 4 plates.

ANDERSON, J.G. and Y. LEI (1994): Nonparametric description of peak acceleration as a function of magnitude, distance, and site in Guerrero, Mexico, Bull. Seismol. Soc. Am., 85, 1003-1017.

ATKINSON, G.M. (1995): Ground motion relations for use in eastern hazard analysis, in Proceedings Seventh Canadian Conference on Earthquake Engineering, Montreal, 1001-1008.

AtKinson, G.M. and D.M. BooRE (1995): New ground motion relations for Eastern North America, Bull. Seismol. Soc. Am., 85, 17-30.

BASHAM, P., D. WEICHERT, F.M. ANGLIN and M.J. BERRY (1985): New probabilistic strong seismic ground motion maps of Canada, Bull. Seismol. Soc. Am., 75, 563-595.

Basham, P., S. Halchuk, D. Weichert and J. AdAMS (1997): New seismic hazard assessment for Canada, Seismol. Res. Lett., 68, 722-726.

BOORE, D.M., W.B. JOYNER and T.E. FuMAL (1993): Estimation of response spectra and peak accelerations from Western North America earthquakes: an interim report, U.S. Geol. Surv. Open-File Rep. 93-509, pp. 72.

BOORE, D.M., W.B. JOYNER and T.E. FuMAL (1997): Equations for estimating horizontal response spectra and peak acceleration from Western North America earthquakes: a summary of recent work, Seismol. Res. Lett., 68, 128-153.

CAMPBELL, K.W. and Y. BozorgniA (1994): Near-source attenuation of peak acceleration from worldwide accelerograms recorded from 1957 to 1993, in Proceedings Fifth National Conference on Earthquake Engineering, EERI, 3, 283-292.

Climent, A., W. Taylor, M.C. Real, W. Strauch, G. SantanA, M. Villlagran, A. Dahle and H. Bungam (1994): Spectral strong motion attenuation in Central
America, NORSAR Tech. Rep. 2-17, pp. 46.

CORNELl, C.A. (1968): Engineering seismic risk analysis, Bull. Seismol. Soc. Am., 58, 1583-1606.

CRAMER, C.H., M.D. PETERSEN and M.S. Reichle (1996): A Monte Carlo approach in estimating uncertainty for a seismic hazard assessment of Los Angeles, Ventura, and Orange Counties, Bull. Seismol. Soc. Am., 86, 1681-1691.

Crouse, C.B. (1991): Ground motion attenuation equations for earthquakes on the Cascadia subduction zone, Earthquake Spectra, 7, 201-236.

DAHLE, A. (1994): NPRISK Users Guide, 1.1, NORSAR, Norway.

DEWEY, J.W. and G. SuÁreZ (1991): Seismotectonics of Middle America, Neotectonics of North America, edited by D.B. SLEMmons, E.R. ENGDAHL, M.D. ZOBACK and D.B. BLACKWELL, GSA DNAG, 309-321.

EsteVA, L. (1970): Regionalización seismica de México para fines de Ingeniería, Serie Azul, Instituto de Ingeniería, UNAM, No. 246, Mexico City.

FRANKEL, A. (1995): Mapping seismic hazard in the Central and Eastern United States, Seismol. Res. Lett., 66, 8-21.

Frankel, A., C. Mueller, T. Barnhard, D. PERKIns, E.V. LEYENDECKER, N. DICKMAN, S. HANSON and M. HOPPER (1996): National seismic hazard maps, U.S. Geol. Surv. Open-File Rep. 96-532, p. 110.

Frankel, A., C. Mueller, T. Barnhard, D. Perkins, E.V. LEYENDECKER, N. DICKMAN, S. HANSON and M. HOPPER (1997a): Seismic hazard maps for California, Nevada, and Western Arizona/Utah, U.S. Geol. Surv. Open-File Rep. 97-130, 12 sheets, scale 1:2000000.

FranKel, A., S. HARMSEN, C. MuEller, T. BARNHARD, E.V. LEYENDECKER, D. PERKINS, S. HANSON, N. DICKMAN and M. HOPPER (1997b): USGS national seismic hazard maps: uniform hazard spectra, deaggregation, and uncertainty, in Proceedings FEMA/ NCEER Workshop on the National Representation of Seismic Ground Motion for New and Existing Bridges, NCEER Pub. 97-0010, F1-F30.

JOYNER, W.B. and D.M. BOORE (1981): Peak horizontal acceleration and velocity from strong motion records from the 1979 Imperial Valley, California earthquake, Bull. Seismol. Soc. Am., 71, 2011-2038.

JOYNER, W.B. and D.M. BOORE (1993): Methods of regression analysis of strong motion data, Bull. Seismol. Soc. Am., 83, 469-487.

KANAMORI, H. (1977): The energy release in great earthquakes, J. Geophys. Res., 82, 2981-2987.

Klein, F., A. Frankel, C. Mueller, R. Wesson and P. OKUBO (1999): Probabilistic seismic hazard maps of Hawaii, U.S. Geol. Surv. Open-File Rep. (in press).

LEYENDECKER, E.V., D.M. PERKIns, S.T. AlgERMISSEN, P.C. THENHAUS and S.L. HANSON (1995): USGS spectral response maps and their relationship with seismic design forces in building codes, U.S. Geol. Sur. Open-File Rep. 95-596, p. 61.

MCGUIRE, R.K. (1993): Computation of seismic hazard, Global Seismic Hazard Assessment Program, edited by D. Giardini and P. BASHAM, Ann. Geofis., 34 (3-4), 181-200.

MCQUEEN, C.M. (1997): An evaluation of seismic hazard in the Caribbean and Central America using three 
probabilistic methods, Ph.D. Thesis, University of Lancaster, pp. 342.

Montero, W., G. PERAldo and W. RoJAs (1997): Seismic Hazard in Latin America and the Caribbean, América Central, IRDC, Ottawa, vol. 3, pp. 79.

Mortgat, C.P., T.C. ZsUTTY, H.C. SHAH and L. LUBETKIN (1977): A study of seismic risk for Coast Rica, Ph.D. Thesis, Stanford University.

Mueller, C., M. Hopper and A. Frankel (1997): Preparation of earthquake catalogs for the national seismic hazard maps: contiguous 48 States, U.S. Geol. Surv. Open-File Rep. 97-464, pp. 36.

Mueller, C., A. Frankel, J. LAHR and M. Wyss (1998): Preparation of earthquake catalogs for the national seismic hazard maps: Alaska, U.S. Geol. Surv. OpenFile Rep. (in preparation).

NEHRP (1994): Recommended Provisions for the Development of Seismic Regulations for New Buildings, prepared by Building Seismic Safety Council for Federal Emergency Management Agency, Washington, D.C.

PEREIRA, J. and D. GAY (1978): An engineering risk anaylsis for Trinidad and Jamaica, in Proceedings, 1st Caribbean Earthquake Engineering Conference, Portof-Spain, Trinidad, 71-92.

Petersen, M., W. Bryant, C. Cramer, T. Cao, M. Reichle, A. Frankel, J. LienKaEMPER, P. MCCRoRY and D. SCHWARTZ (1996): Probabilistic seismic hazard assessment for the state of California; CA Div. Mines and Geol. Open-File Rep. 96-08, p. 66 and U.S. Geol. Surv. Open-File Rep. 96-706, p. 66.

Rogers, G.C. and R.B. Horner (1991): An overview of Western Canadian seismicity, in Neotectonics of North America, edited by D.B. SLEMMONS, E.R. ENGDAHL, M.D. ZOBACK and D.B. BLACKWELL, GSA DNAG, 69-76.

Rojas, W., H. Bungam and C. Lindholm (1993): A catalog of recent and historical earthquakes in Central America, NORSAR Tech. Rep. 2-7, p. 78.

Rosenblueth, E., M. ORDAZ, F.J. SÁNCHEZ-SESMA and S.K. SINGH (1989): Design spectra for México's Federal District, Earthquake Spectra, 5, 273-291.

SADIGH, K., C.-Y. CHANG, J.A. EGAN, F. MAKDISI and R.R. Youngs (1997): Attenuation relationships for shallow crustal earthquakes based on California strong motion data, Seismol. Res. Lett., 68, 180-189.

SATAKE, K., K. SHIMAZAKI, Y. TSUJI and K. UYEDA (1996): Time and size of a giant earthquake in Cascadia inferred from Japanese tsunami records of January 1700 Nature, 379, 246-249.

SHEPHERD, J.B. (1993): Seismic hazard in the Eastern Caribbean, in The Practice of Earthquake Hazard Assessment, edited by R.K. MCGUIRE, IASPEI, Denver, 51-55.

SHEPHERD, J.B. and W.P. ASPINALL (1983): Seismicity and earthquake hazard in Trinidad and Tobago, West Indies, Earthquake Eng. Struct. Dyn., 11, 229-250.

SHEPHERD, J.B., J.G. TANNER, C.M. MCQUEEN and L.L. LYNCH (1997): Seismic hazard in Latin America and the Caribbean, Seismic Hazard Maps for the Caribbean, IRDC, Ottawa, vol. 5, pp. 15.

SINGH, S.K., R. APSEL, J. FRIED and J.N. BRUNE (1982): Spectral attenuation of $S H$-waves along the Imperial Fault, Bull. Seismol. Soc. Am., 72, 2003-2016.

TANNER, J.G. and J.B. SHEPHERD (1997): Seismic hazard in Latin America and the Caribbean, Project Catalog and Seismic Hazard Maps, IRDC, Ottawa, vol. 1, p. 143.

TAYLOR, L.O., W.P. ASPINALL and P. MORRIS (1978): A preliminary analysis of seismic risk in the Lesser Antilles, in Proceedings 1st Caribbean Earthquake Engineering Conference, Port-of-Spain, Trinidad, 10-27.

ToRo, G.R., N.A. ABRAHAMSON and J.F. SCHNEIDER (1997): Model of strong ground motions from earthquakes in Central and Eastern North America: best estimates and uncertainties, Seismol. Res. Lett., 68,
41-57.

Veneziano, D., C.A. CoRnell and T. O'HARA (1984): Historical method of seismic hazard analysis, Electr. Power Res. Inst. Rep. NP-3438, Palo Alto.

WESSEL, P. and W.H. SMITH (1995): GMT Version 3 Technical Reference and Cookbook, NOAA N/OES12, pp. 92.

Wesson, R.L., A.D. FranKel, C.S. Mueller and S.C. HARMSEN (1999): Probabilistic seismic hazards maps of Alaska, U.S. Geol. Surv. Open-File Rep. (in press).

WoODWARD-Clyde CONSUltanTs (1982): Development and initial application of software for seismic exposure evaluation, Report for NOAA, II.

YounGS, R.R., S.-J. CHIOU, W.L. SILVA and J.R. HuMPHREY (1997): Strong ground motion attenuation relationships for subduction zone earthquakes, Seismol. Res. Lett., 68, 58-73.

ZÚÑIGA, R., G. SUÁrez, M. ORdAZ and V. GARCÍAACOSTA (1997): Seismic Hazard in Latin America and the Caribbean, México, IDRC, Ottawa, vol. 2, pp. 82. 